\title{
Tunnel growth mechanism of aluminum foils during etching on corrosion cell
}

\author{
D. Xu ${ }^{1}$, R.-G. Xiao*1, J.-Z. Wang ${ }^{2}$ \\ ${ }^{1}$ Department of Chemistry and Chemical Engineering, Guizhou University, Guiyang, 550003, P. R. China \\ ${ }^{2}$ Jiangsu United Technology Group Co., Nantong, 226361, P. R. China
}

Received 20 May 2018, received in revised form 27 July 2018, accepted 6 September 2018

\begin{abstract}
The corrosion cell is exploited to enhance the effective surface area of high-purity aluminum foils for aluminum electrolytic capacitors by forming tunnels. The morphology of tunnels is characterized, and the growth mechanism is discussed. Detailed investigations indicate that tunnels could grow only when nitric acid was added into the mixed acid electrolyte in the corrosion cell. Also, the tunnel morphology in the aluminum foil is relevant to the concentration of nitric acid and hydrochloric acid. In the mixed electrolyte solution that consists of 3.0 mol L ${ }^{-1} \mathrm{H}_{2} \mathrm{SO}_{4}, 1.0 \mathrm{~mol} \mathrm{~L}{ }^{-1} \mathrm{HCl}$ solution and $0.2 \mathrm{~mol} \mathrm{~L}^{-1} \mathrm{HNO}_{3}$, the current density of the corrosion cell on the aluminum foil surface can reach $0.2 \mathrm{~A} \mathrm{~cm}^{-2}$, which leads to square tunnels of high density on the surface of aluminum foils. The length and width of the tunnels are about 25-30 and $2 \mu \mathrm{m}$, respectively. The morphology of the tunnels is similar to that obtained by DC etching. The current results indicate that the generation of tunnels has a close correlation with the hydrogen evolution corrosion and oxygen absorption corrosion in the corrosion cell.
\end{abstract}

K e y words: aluminum foil, aluminum electrolytic capacitor, tunnels, corrosion cell

\section{Introduction}

The rapid development of the electronic industry promotes massive production and wide-spread applications of aluminum electrolytic capacitors, which is smaller than other capacitors but has a greater capacity per volume. It is well known that the capacitance of aluminum electrolytic capacitors is determined by the surface area of the aluminum foil electrodes. DC or AC etching is usually considered to be an effective method of increasing the surface area of aluminum foils. The growth of pits using high-purity aluminum during DC etching in hot $\mathrm{HCl}$ solutions has been investigated with respect to the effect of electrolyte conditions on the pit shape [1], morphology of the early stages of the pitting corrosion [2], the tunnel pit growth rate [3], the effect of impurities on the DC etching behavior $[4,5]$, the influence on the etch pit width and tunnel length [6], the tunnel growth effect after preprocessing with polymeric corrosion inhibitor before DC etching [7], and other methods assisting DC etching [8].
In general, many previous works have investigated the tunnel growth in aluminum foils by $\mathrm{DC}$ or $\mathrm{AC}$ etching [9-15]. However, whether a tunnel can grow without any DC or AC power has barely been studied. In this work, we report a corrosion cell-based etching process of high purity aluminum foils in a corrosion cell, aiming to develop a novel method for producing aluminum foils with the high specific surface area. The aluminum foil was immersed in the solution of $\mathrm{H}_{2} \mathrm{SO}_{4}-\mathrm{HCl}-\mathrm{HNO}_{3}$ in a corrosion cell that uses the Al foil and graphite as the electrodes (Fig. 1). Tunnels with defined morphologies were produced in the Al foils. The current density on the surface aluminum foil was determined, and the tunnel morphology was characterized by scanning electron microscope. The kinetics process of electrode reactions was also analyzed. The width and length of the tunnels have a size of about 2 and $30 \mu \mathrm{m}$, respectively, which is similar to the tunnel morphology obtained by DC etching. Therefore, the current corrosion cell can be used to enlarge the surface area of aluminum foils for aluminum electrolytic capacitors. The current method is

*Corresponding author: e-mail address: rgxiao@gzu.edu.cn 
Table 1. Element content in the aluminum foil (\%)

\begin{tabular}{ccccccc}
\hline $\mathrm{Al}$ & $\mathrm{Cu}$ & $\mathrm{Fe}$ & $\mathrm{Zn}$ & $\mathrm{Mn}$ & $\mathrm{Si}$ & $\mathrm{Cr}$ \\
\hline 99.991 & 0.0048 & 0.0016 & 0.0010 & 0.0003 & 0.0002 & 0.0002 \\
\hline
\end{tabular}

environment-friendly because the etching process can be performed without any external current source.

\section{Experimental}

\subsection{Materials}

The material used in the etching experiments was the commercial aluminum foil (99.998 wt.\%) for highvoltage electrolytic capacitors. The percentage content of the elements is shown in Table 1. Sulfuric acid (analytically pure), hydrochloric acid (analytically pure), nitric acid (analytically pure), sodium hydroxide, titanium dioxide, isopropyl alcohol, dibutyl phthalate, perchloric acid and absolute ethyl alcohol were used as received.

\subsection{Etching aluminum foils in the corrosion cell}

The configuration of the corrosion cell for the electrochemical etching of aluminum foils is shown in Fig. 1. Graphite plates were used as the counter electrode, and the aluminum and graphites were directly connected with wires. The electrolyte consisted of $3 \mathrm{~mol} \mathrm{~L}^{-1} \mathrm{H}_{2} \mathrm{SO}_{4}$ and $1 \mathrm{~mol} \mathrm{~L}^{-1} \mathrm{HCl}$, to which $0-0.3$

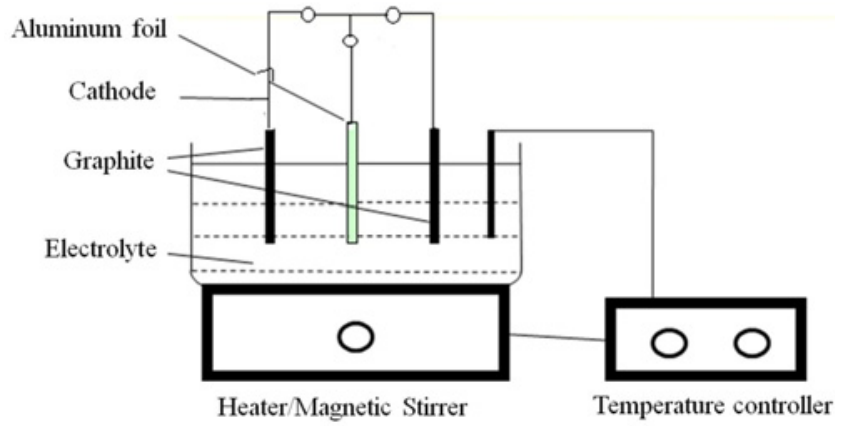

Fig. 1. Schematic description of the corrosion cell for aluminum foil etching.

mol L ${ }^{-1} \mathrm{HNO}_{3}$ was added. The etching was carried out for $5 \mathrm{~min}$ at $75^{\circ} \mathrm{C}$. The foil was rinsed with deionized water after etching.

\subsection{Characterization of the morphology of etched Al foils}

The morphology of tunnels was characterized using a ZEISS SIGMA scanning electron microscopy (SEM). The cross section of aluminum foil was first polished with the mechanical and electrochemical method and then characterized with metalloscope.

\section{Results and discussion}

\subsection{Influence of nitric acid concentration on tunnels morphology}

To reveal the role of nitric acid on the tunnel mor-
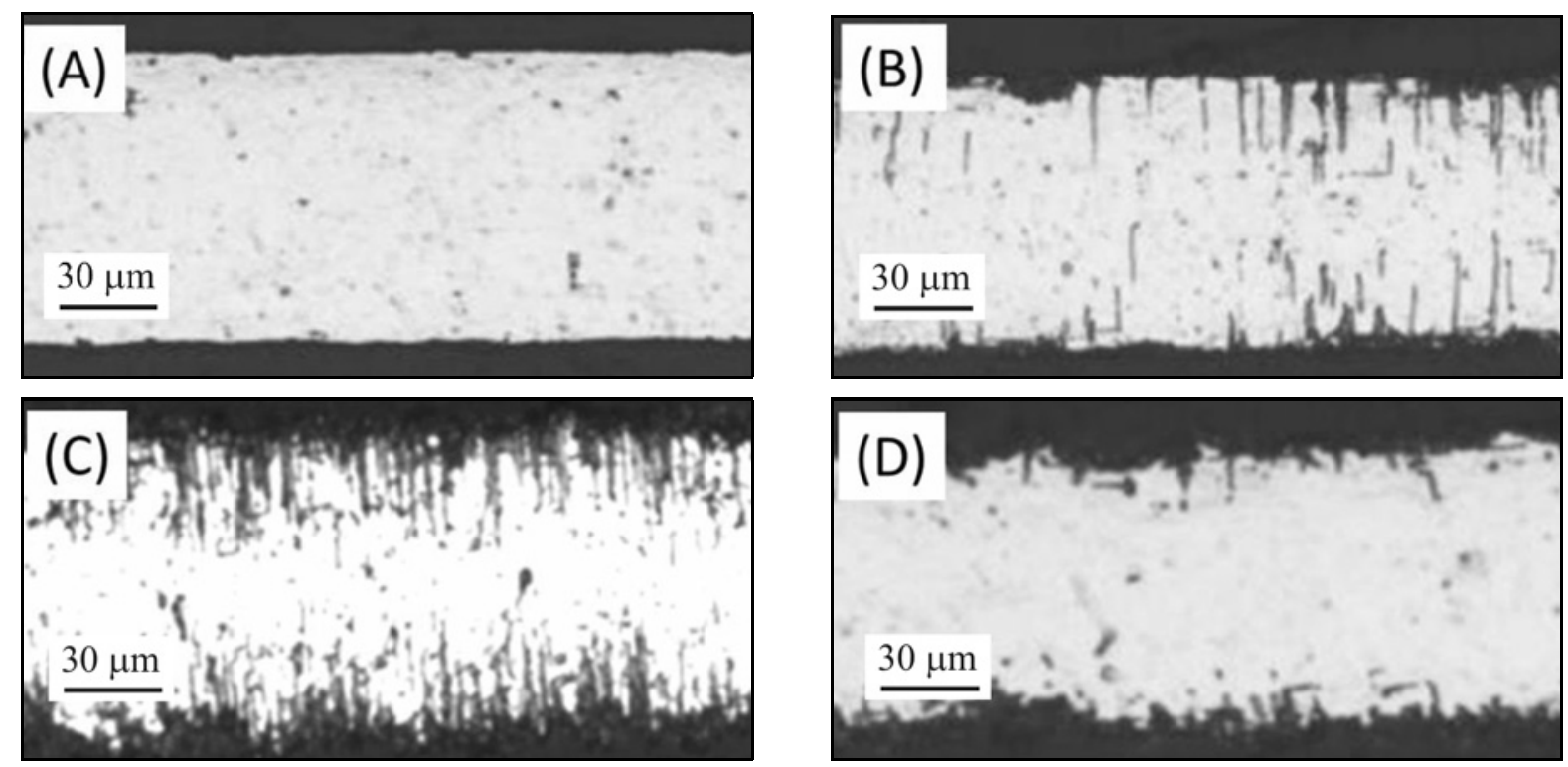

Fig. 2. Cross-section images of aluminum foils after etching at different concentrations of nitric acid. $(\mathrm{A}): 0 \mathrm{~mol} \mathrm{~L} \mathrm{~L}^{-1} ;(\mathrm{B})$ : $0.1 \mathrm{~mol} \mathrm{~L}^{-1} ;(\mathrm{C}): 0.2 \mathrm{~mol} \mathrm{~L}^{-1} ;(\mathrm{D}): 0.3 \mathrm{~mol} \mathrm{~L}^{-1}$. 
phology of etched aluminum foils, the concentration of nitric acid was varied in the corrosion cell consisting of the high-purity $\mathrm{Al}$ foil and graphites while sulfuric acid and hydrochloric acid of the corrosion liquids were fixed at 3 and $1 \mathrm{~mol} \mathrm{~L}{ }^{-1}$, respectively. The etching was always performed at $75^{\circ} \mathrm{C}$. After corrosion, the cross-section metallographic phase of the aluminum foil was checked with SEM and is shown in Fig. 2. As revealed by Fig. 2, in the absence of nitric acid in the electrolyte, no tunnel on the surface of aluminum foil can be observed. Only in the presence of nitric acid can the corrosion cell-based etching process generate tunnels in the aluminum foil. Furthermore, the tunnel density is relevant to the concentration of nitric acid $\left(C_{\mathrm{ni}}\right)$. At $C_{\mathrm{ni}}=0.1 \mathrm{~mol} \mathrm{~L}^{-1}$, tunnels can be observed. The tunnel density increases when $C_{\text {ni }}$ increases to 0.2 mol L ${ }^{-1}$. However, further increase of nitric acid leads to decreased tunnel density, which is because the surface corrosion of the aluminum foil becomes dominant (Fig. 2D).

To understand the effect of $\mathrm{HNO}_{3}$ on the corrosion current of aluminum foil in the corrosion cell, the current density was determined in the electrolyte of $3.0 \mathrm{~mol} \mathrm{~L}^{-1} \mathrm{H}_{2} \mathrm{SO}_{4}$ and $1.0 \mathrm{~mol} \mathrm{~L}^{-1} \mathrm{HCl}$, to which $\mathrm{HNO}_{3}$ with different concentration was added (Fig. 3). Figure 3 shows that the corrosion current density increases with the concentration of $\mathrm{HNO}_{3}$ in the elec-

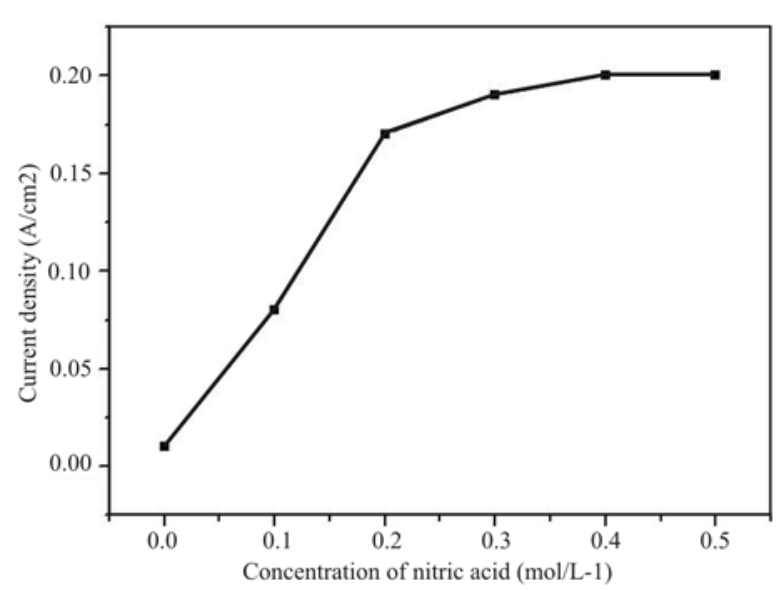

Fig. 3. The relation between current density on aluminum foils surface and concentration of $\mathrm{HNO}_{3}$ in the electrolyte of the corrosion cell.

trolyte and eventfully levels off when the nitrate concentration increased to $0.3 \mathrm{~mol} \mathrm{~L}{ }^{-1}$. After this concentration, the current density increases slowly with increasing concentration of nitric acid and finally a maximum value of $0.20 \mathrm{~A} \mathrm{~cm}^{-2}$ was achieved. Therefore, the limiting current density of the aluminum foil surface is $0.2 \mathrm{~A} \mathrm{~cm}^{-2}$ in a corrosion cell in the system.
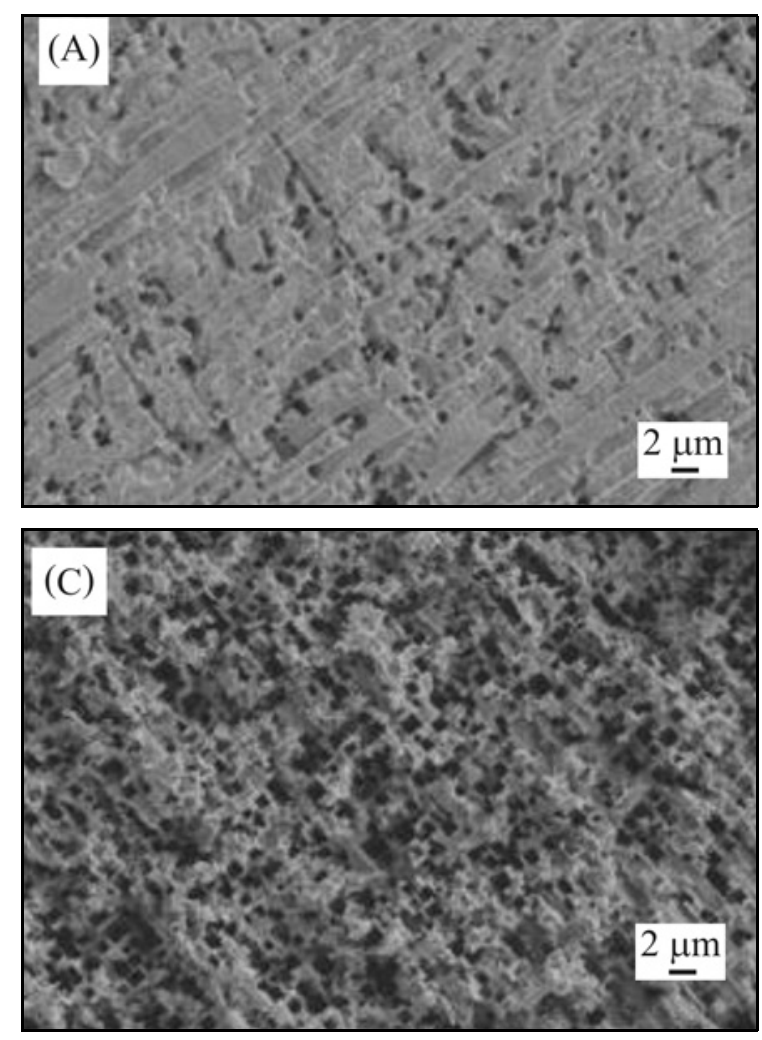
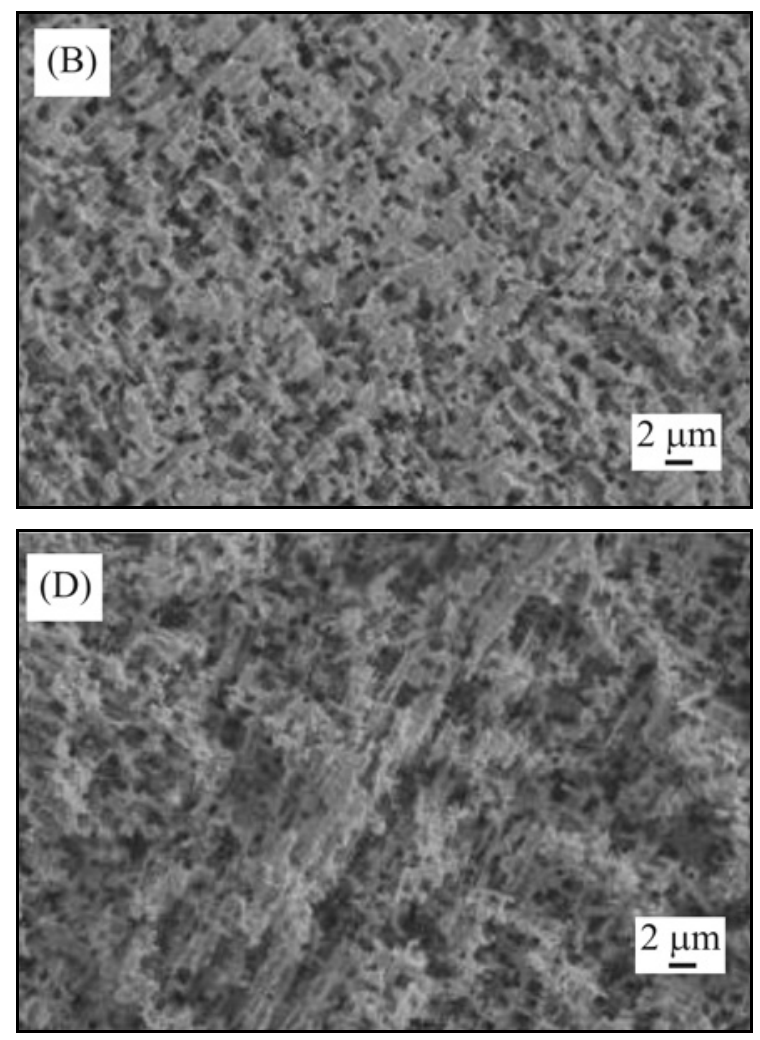

Fig. 4. SEM of the aluminum foil surface after etching in the corrosion cell in the electrolyte $3 \mathrm{~mol} \mathrm{~L}^{-1} \mathrm{H}_{2} \mathrm{SO}_{4}+1 \mathrm{~mol} \mathrm{~L}^{-1}$ $\mathrm{HCl}$ and (A) $0.0 \mathrm{~mol} \mathrm{~L}^{-1} \mathrm{HNO}_{3}$; (B) $0.1 \mathrm{~mol} \mathrm{~L}^{-1} \mathrm{HNO}_{3}$; (C) $0.2 \mathrm{~mol} \mathrm{~L}^{-1} \mathrm{HNO}_{3}$; (D) $0.3 \mathrm{~mol} \mathrm{~L}^{-1} \mathrm{HNO}_{3}$. 

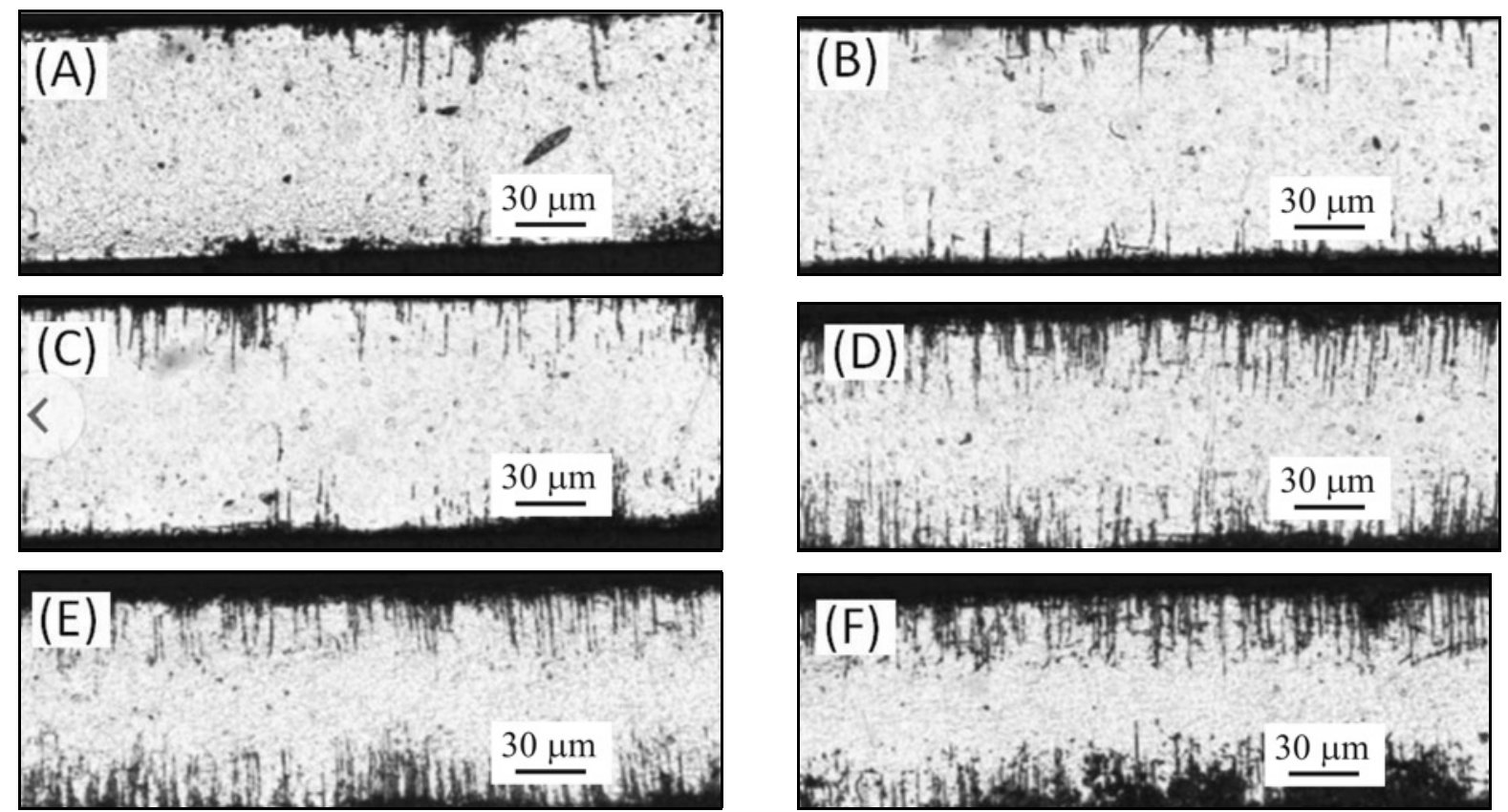

Fig. 5. Cross-section images of aluminum foils after etching in corrosion cell at different $\mathrm{HCl}$ concentration: (A) $0.3 \mathrm{~mol} \mathrm{~L}{ }^{-1}$; (B) $0.5 \mathrm{~mol} \mathrm{~L}^{-1}$; (C) $0.7 \mathrm{~mol} \mathrm{~L}^{-1}$; (D) $0.9 \mathrm{~mol} \mathrm{~L}^{-1}$; (E) $1.1 \mathrm{~mol} \mathrm{~L}^{-1}$; (F) $1.3 \mathrm{~mol} \mathrm{~L}^{-1}$.

Figure 4 shows the surface morphology of the aluminum foil etched in the corrosion cell. It is clear that the size of tunnels is about $1 \mu \mathrm{m}$, which is similar to the tunnels in the aluminum foil etched by DC [1]. There are only a few tunnels in the absence of $\mathrm{HNO}_{3}$ (Fig. 4A). However, many tunnels appear when $\mathrm{HNO}_{3}$ was added, and the density of the tunnels increased when the concentration of $\mathrm{HNO}_{3}$ increased up to 0.3 mol L ${ }^{-1}$. After this concentration, the density of tunnels starts to decrease, and the surface of aluminum foil also becomes irregular. Figure $4 \mathrm{C}$ shows that the density of tunnels almost reaches $10^{7} \mathrm{~cm}^{-2}$.

\subsection{Influence of the concentration of $\mathrm{HCl}$ in the corrosion cell on the morphology of tunnels}

N. Osawa [16] and E. McCafferty [17] have suggested that chloride ions attack $\mathrm{Al}$ metal during $\mathrm{DC}$ or AC etching, and the pitting potential is dependent of the concentration of chloride ions in the electrolyte. To understand the electrode kinetics of pitting in aluminum foil etched in the current corrosion cell, the influence of hydrochloric acid on the morphology of tunnels of the etched aluminum foil is summarized in Fig. 5. For this, the corrosive liquid consisted of $3 \mathrm{~mol} \mathrm{~L}^{-1} \mathrm{H}_{2} \mathrm{SO}_{4}$ and $0.2 \mathrm{~mol} \mathrm{~L}^{-1} \mathrm{HNO}_{3}$ while the concentration of hydrochloric acid varied from 0.3 to $1.3 \mathrm{~mol} \mathrm{~L}^{-1}$. It is clear that the concentration of hydrochloric acid in the corrosive liquid also has a significant influence on the corrosion of the $\mathrm{Al}$ foil. With the increasing concentration of hydrochloric acid, the surface of the aluminum foil changes from the pure sur- face corrosion into the pore corrosion that generates tunnel-holes. The density of tunnels increases when increasing the concentration of $\mathrm{HCl}$ in the electrolyte. Although there is barely tunnel grow when the concentration of $\mathrm{HCl}$ is less than $0.3 \mathrm{~mol} \mathrm{~L}^{-1}$, the density of tunnels increases enormously when the concentration of $\mathrm{HCl}$ is $0.9 \mathrm{~mol} \mathrm{~L}^{-1}$. Also, the concentration of $\mathrm{HCl}$ almost does not affect the limit of tunnel length. This conclusion seems to be contrary to other researchers' conclusions, but because the current density has a direct effect on the length of the tunnel during etching on corrosion cell, so the effect of the chloride concentration on the tunnel length is not so obvious in the new etching method.

\subsection{Discussion}

It is well known that there are some conditions for tunnel growth in aluminum foil during DC etching: on the one hand, it needs enough concentration of $\mathrm{Cl}^{-}$ to attack aluminum. On the other hand, tunnels can grow when the current density on the top of the tunnel is large enough. Figures 4 and 5 show that there is no obvious morphologic difference between tunnels by DC etching or in corrosion cell. Therefore it is very important for tunnels on the surface of aluminum foil to grow in corrosion cell. Figure 2 shows that the concentration of $\mathrm{HNO}_{3}$ in the electrolyte is a key factor for the tunnel growth. The electrode reactions are as follows when the electrolyte consists of $3.0 \mathrm{~mol} \mathrm{~L}^{-1}$ $\mathrm{H}_{2} \mathrm{SO}_{4}$ and $1.0 \mathrm{~mol} \mathrm{~L}^{-1} \mathrm{HCl}$ :

$$
\text { Anode (aluminum foil): } \mathrm{Al} \rightarrow \mathrm{Al}^{3+}+3 \mathrm{e}^{-},
$$


Cathode (graphite): $2 \mathrm{H}^{+}+2 \mathrm{e}^{-} \rightarrow \mathrm{H}_{2}$.

Under this condition, Fig. 3 shows that the current density on the surface of the aluminum foil is only 0.01 $\mathrm{A} \mathrm{cm}^{-2}$. Figure $4 \mathrm{~A}$ indicates that there are some pits on the surface of aluminum, but pits cannot grow into tunnels. It is hard to find any tunnel in Fig. 2A.

After the $\mathrm{HNO}_{3}$ solution was added into the electrolyte in the corrosion cell, the electrode reaction in the electrolyte changes due to the decomposition of nitric acid:

$$
4 \mathrm{HNO}_{3} \rightarrow \mathrm{O}_{2}+4 \mathrm{NO}_{2}+2 \mathrm{H}_{2} \mathrm{O}
$$

The decomposition of nitric acid produces oxygen, which leads to the oxygen absorption corrosion reaction at the cathode. Thus, the electrode reactions in the electrolyte are as follows:

$$
\begin{aligned}
& \text { Anode }: \mathrm{Al} \rightarrow \mathrm{Al}^{3+}+3 \mathrm{e}^{-}, \\
& \text {Cathode }: 2 \mathrm{H}^{+}+2 \mathrm{e} \rightarrow \mathrm{H}_{2}, \\
& 2 \mathrm{H}_{2} \mathrm{O}+\mathrm{O}_{2}+2 \mathrm{e} \rightarrow 4 \mathrm{OH}^{-}
\end{aligned}
$$

Therefore, when the aluminum foil and the graphite electrodes are connected, and nitric acid is added (Fig. 1), the anode reaction remains unchanged while the oxygen absorption corrosion reaction is added to the cathode reaction. This enhanced reaction turns this system into a corrosion cell and enhances the cathode reaction current of the aluminum foil during the chemical corrosion. The whole system becomes a reaction with characteristics of the small anode and big cathode. This kind of reaction intensifies the chemical corrosion and increases the surface current density of the aluminum foil, leading to the generation of tunnels that grow on the aluminum foil surface (100) crystal plane.

At the same time, in the corrosion cell, the nitric acid is resolved to $\mathrm{NO}_{2}$ which plays the role of transferring electrons in the electrode reaction process. The electrode reactions are as follows:

$$
\begin{gathered}
\mathrm{NO}_{2}+\mathrm{e} \rightarrow \mathrm{NO}_{2}^{-}, \\
\mathrm{NO}_{2}^{-}+\mathrm{H}^{+} \rightarrow \mathrm{HNO}_{2}, \\
\mathrm{HNO}_{2}+\mathrm{HNO}_{3} \rightarrow \mathrm{NO}_{2} \mathrm{H}_{2} \mathrm{O} .
\end{gathered}
$$

Chemical Eqs. (7)-(9) show that $\mathrm{NO}_{2}$ accelerates the cathode reaction process and regenerates during etching. In this way, the current density in the corrosion cell increases from 0.01 to $0.2 \mathrm{~A} \mathrm{~cm}^{-2}$.

The schematic description of the cathode reaction process is shown in Fig. 6. Figure 6a shows the cathode reaction process without $\mathrm{HNO}_{3}$ in the electrolyte,
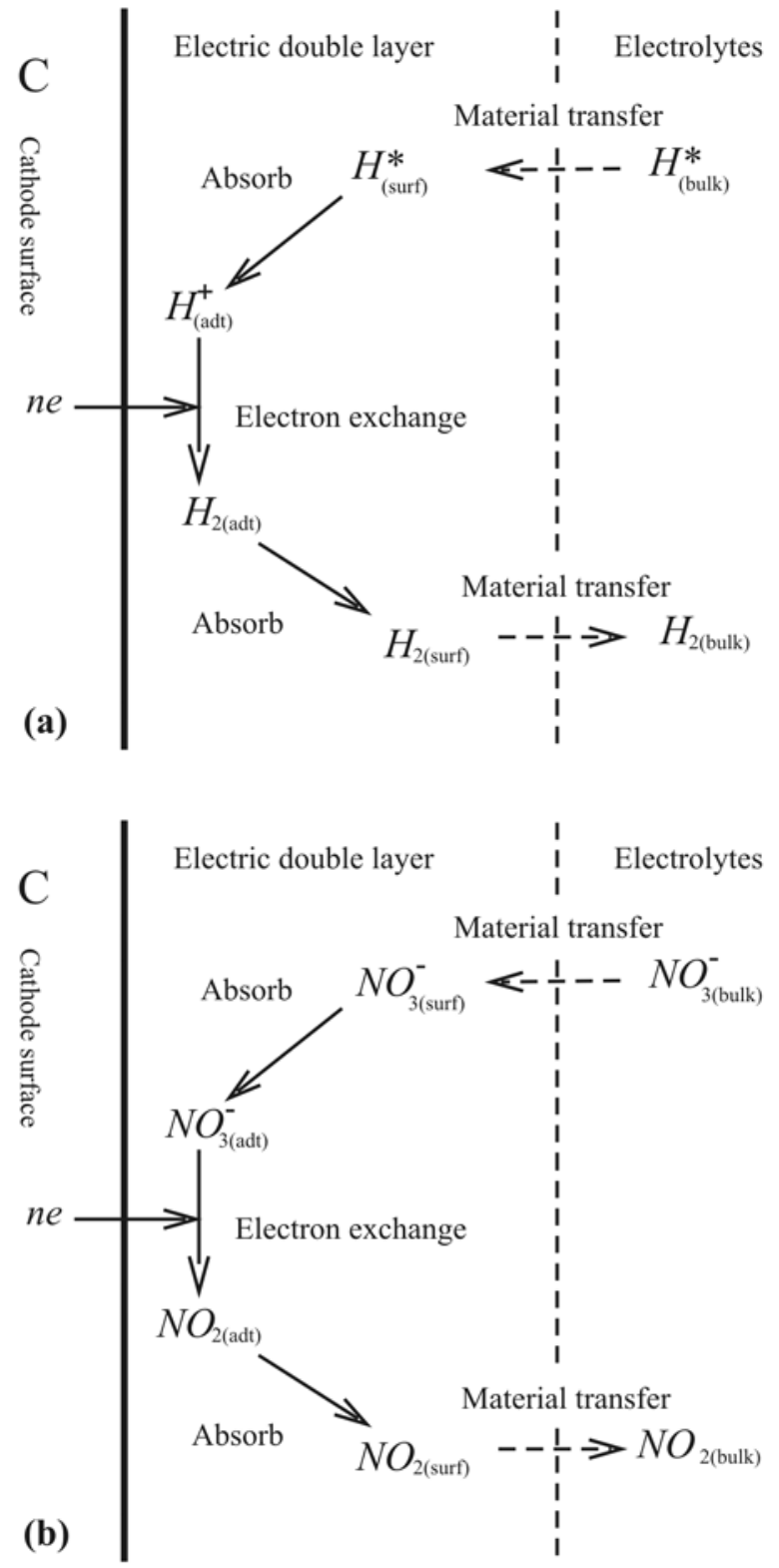

Fig. 6 Schematic description of the cathode reaction process (A) without $\mathrm{HNO}_{3}$ in the electrolyte; (B) with $\mathrm{HNO}_{3}$ in the electrolyte.

Fig. $6 \mathrm{~b}$ shows the cathode reaction process after $\mathrm{HNO}_{3}$ is added to the electrolyte. Chemical equation Eq. (7) shows the cathode electrode reaction rate depends on the concentration of $\mathrm{NO}_{2}$ when $\mathrm{NO}_{2}$ yields a saturated solution; electrode transaction rate reaches a limit value. Figure 3 indicates that the limit current density is $0.2 \mathrm{~A} \mathrm{~cm}^{-2}$ in the corrosion cell. So $\mathrm{NO}_{2}$ speeds up the transfer of electrons at the cathode in corrosion cell, at the same time, the current density on the surface of aluminum foil increases, tunnels grow to enlarge the surface area of the aluminum foil.

Figure 7 shows the SEM image of aluminum etched 


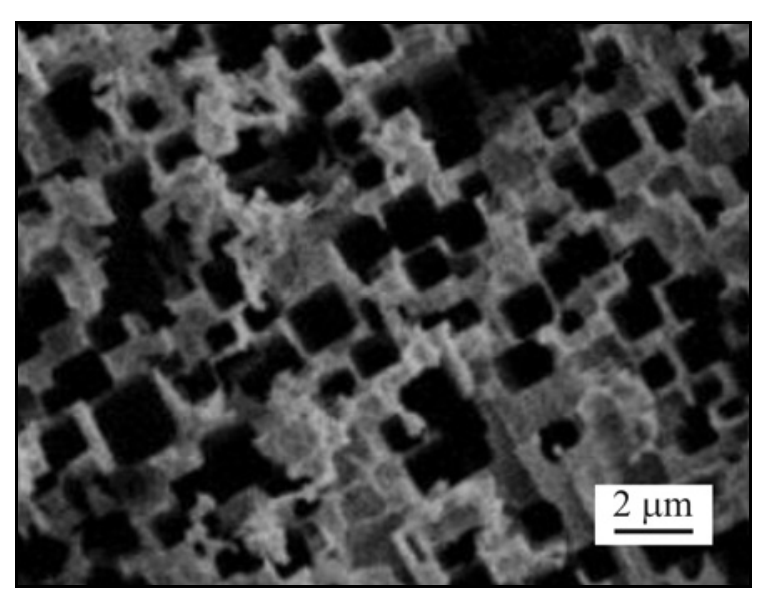

Fig. 7. SEM image of aluminum etched in corrosion cell for $5 \mathrm{~min}$.
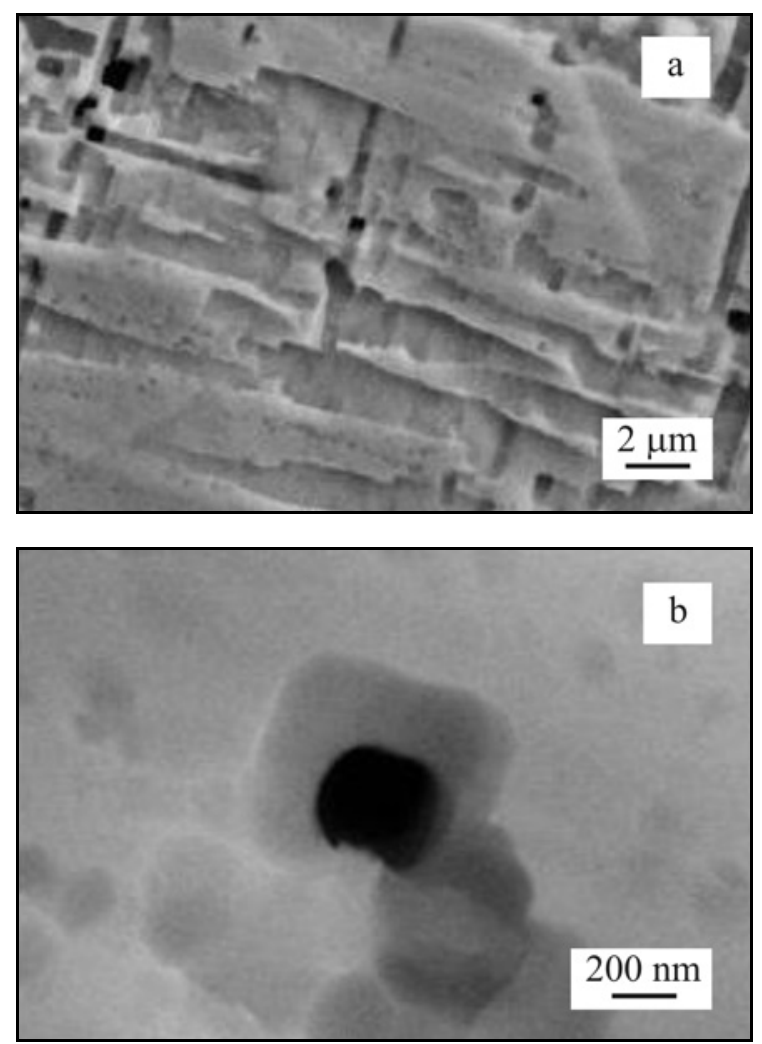

Fig. 8. SEM image of aluminum etched in corrosion cell for $1 \mathrm{~min}$.

in corrosion cell for 5 min. The size of most tunnels is larger than $1 \mu \mathrm{m}$. It is well known that the size of tunnels etched by DC etching is about $1 \mu \mathrm{m}$ so that the tunnel growth mechanism may be different between DC etching and corrosion cell method. The tunnel walls are passivated during tunnel growth when DC etching, while the tunnel walls are activated when aluminum etched in corrosion cell. Figure 8 shows the

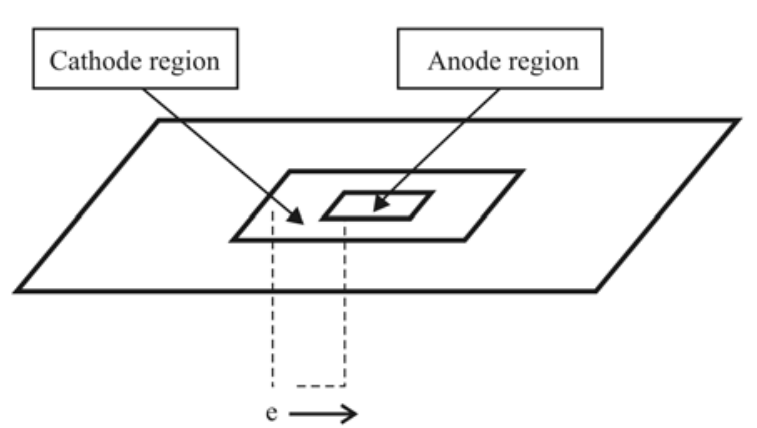

Fig. 9. Schematic description of the tunnel growth process in corrosion cell.

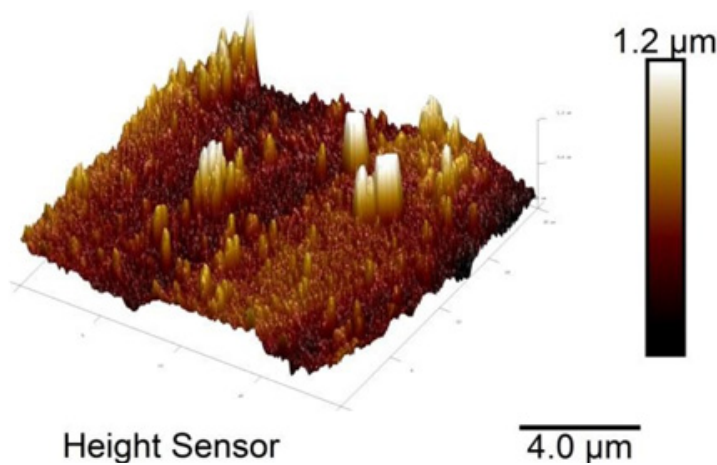

Fig. 10. AFM image of aniline polymer.

SEM image of aluminum etched in corrosion cell for 1 minute; Fig. 8 indicates that the boundary around tunnels walls may be etched continually. So the size of tunnels is larger than $1 \mu \mathrm{m}$.

Figure 9 shows the schematic description of the tunnel growth process in the corrosion cell. On the surface of aluminum, anode region, and cathode region which composed corrosion cell close together, the cathode region must be large enough to provide current for tunnel growth in the anode region, so the anode region is enclosed by cathode region, along with tunnel growth. The resistance between anode and cathode slowly becomes greater, the current at the top of the tunnel becomes smaller, so that the tunnel stops growing, while the new anode region appears at the edge of the tunnel, so the size of the tunnel becomes larger. The tunnel morphology is shown in Fig. 8.

To improve the tunnels morphology on the surface of aluminum, aniline polymer was covered on the aluminum surface based on the electropolymerization method; the surface morphology has been imaged by atomic force microscopy. Figure 10 shows the image of aniline polymer; the thickness is about several $\mathrm{nm}$, many columns appear on the surface of aluminum.

Figure 11 shows the SEM image of aluminum covered with aniline polymer after etching in the corrosion cell. Figure 11 indicates that the tunnel size is 


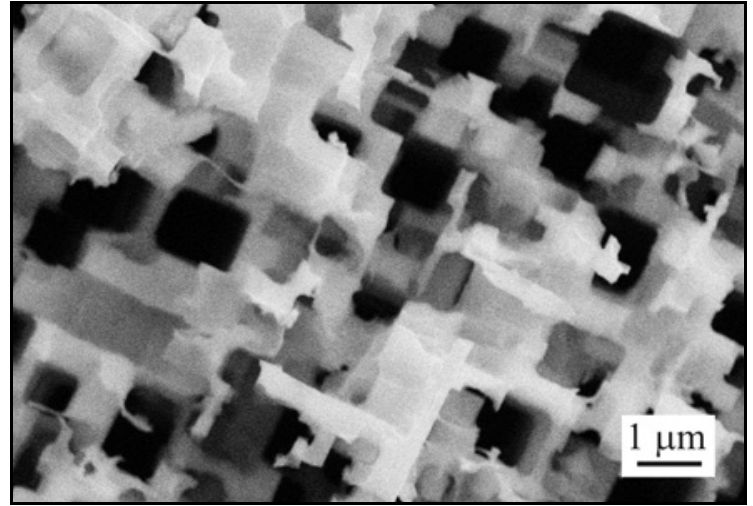

Fig. 11. SEM image of aluminum covered with aniline polymer.

about $1 \mu \mathrm{m}$, so the aniline polymer has effect on tunnels growth model, because the aniline polymer is conductive material, on one hand, the gaps point between columns on the surface of aluminum is more easily to be etched in corrosion cell, on the other hand, the aniline polymer was used to protect aluminum etching, so the tunnel edge could not be etched.

\section{Conclusions}

In summary, the corrosion cell consisting of highpurity aluminum foils and graphite was designed to enlarge the surface area of aluminum foils for aluminum electrolytic capacitors by producing tunnels in the Al foils. The current density in corrosion cell is dependent on the constituents of the electrolyte. Experiments indicate that the current density increased with $\mathrm{HNO}_{3}$ concentration when the mixture of $\mathrm{H}_{2} \mathrm{SO}_{4}-\mathrm{HCl}$ $-\mathrm{HNO}_{3}$ was used as the electrolyte, and the current density increased from 0.01 to $0.2 \mathrm{~A} \mathrm{~cm}^{-2}$. $\mathrm{NO}_{2}$ in the electrolyte speed up the transfer of electrons at the cathode in corrosion cell, so when $\mathrm{NO}_{2}$ reaches saturation, the current density reaches the maximum value of $0.2 \mathrm{~A} \mathrm{~cm}^{-2}$. The width and length of the tunnels have a size of about 2 and $30 \mu \mathrm{m}$, respectively, which is similar to the tunnel morphology obtained by DC etching, but the tunnel width is larger than that etched by DC etching. The results indicate that tunnels walls are active during growing, and the aniline polymer on the surface of aluminum has an effect on tunnels growth model. Therefore, the current corrosion cell can be used to enlarge the surface area of aluminum foils for aluminum electrolytic capacitors.

\section{Acknowledgements}

This work was supported by Guizhou Natural Science Foundation ([2016]7438) and the Natural Science Foundation of Shandong Province, China (Grant No. ZR2017MEM019).

\section{References}

[1] Alwitt, R. S., Uchi, H., Beck, T. R., Alkire, R. C.: J. Electrochem. Soc., 131, 1984, p. 13. doi:10.1149/1.2115495

[2] Wiersma, B. J., Hebert, K. R.: J. Electrochem. Soc., 138, 1991, p. 48. doi:10.1149/1.2085577

[3] Osawa, N., Fukuoka, K., Tanabe, Y.: J. Surf. Finish. Soc. Jap., 42, 1991, p. 236. doi:10.4139/sfj.42.236

[4] Lin, W., Tu, G. C., Lin, C. F., Peng, Y. M.: Corros. Sci., 38, 1996, p. 889. doi:10.1016/0010-938X(96)00175-8

[5] Ban, C. L., Zhu, S. Q., Hou, J. L., Wang, F. R., Wang, J.: J. Mater. Sci.: Mater. Electron., 28, 2017, p. 6860. doi:10.1007/s10854-017-6385-9

[6] Ryu, J.-H., Seo, J. H., Jeong, J.-H., Kim, S.-K., Lee, D. N.: J. Appl. Electrochem., 34, 2004, p. 879. doi:10.1023/B:JACH.0000040439.04947.f4

[7] Ban, C., He, Y., Shao, X., Wang, Z.: Corros. Sci., 78, 2014, p. 7. doi:10.1016/j.corsci.2013.07.011

[8] Ban, C., Zhu, S., Tao, X., Chen, W. J.: Mater. Sci.: Mater. El., 27, 2016, p. 12074. doi:10.1007/s10854-016-5356-x

[9] Jeong, J. H., Kim, S. S., Kim, H. G., Choi, C. H., Lee, D. N.: Materials Science Forum, 217-222, 1996, p. 1565 . doi:10.4028/www.scientific.net/MSF.217-222.1565

[10] Zhong, H., Okido, M., Oki, T.: J. Surf. Fin. Soc., 45, 1994, p. 1059. doi:10.4139/sfj.45.1059

[11] Goad, D.: J. Electrochem. Soc., 144, 1997, p. 1965. doi: $10.1149 / 1.1837730$

[12] Ryu, J.-H., Seo, J. H., Jeong, J.-H., Kim, S.-K., Lee, D. N.: J. Appl. Electrochem., 34, 2004, p. 879. doi:10.1023/B:JACH.0000040439.04947.f4

[13] Yi, Q.-X., He, Y.-D., Peng, N., Song, H.-Z., Yang, X.F., Cai, X.-Y.: Int. J. Min. Met. Mater., 23, 2016, p. 70. doi:10.1007/s12613-016-1212-5

[14] Liang, L., He, Y., Song, H., Yang, X., Cai, X.: Corros. Sci., 79, 2014, p. 21. doi:10.1016/j.corsci.2013.10.017

[15] Xiao, R.-G., Yan, K.-P., Yan, J.-X., Wang, J.-Z.: Corros. Sci., 50, 2008, p. 1576. doi:10.1016/i.corsci.2008.02.017

[16] Osawa, N., Fukuoka, K.: Corros. Sci., 42, 2000, p. 585. doi:10.1016/S0010-938X(99)00117-1

[17] McCafferty, E.: Corros. Sci., 37, 1995, p. 481. doi:10.1016/0010-938X(94)00150-5 